\title{
Lessons from Translation of a Historical Novel from Tamil to English
}

\section{RAJENDRAN SANKARAVELAYUTHAN}

Historical novel is a novel that has as its setting a period of history and that attempts to convey the spirit, manners, and social conditions of a past age with realistic detail and fidelity (which is in some cases only apparent fidelity) to historical fact. The work may deal with actual historical personages, or it may contain a mixture of fictional and historical characters. The historical novel Ponniyin Selvan taken for our analysis is a mixture of fictional and historical characters. The events are also both historical and fictional. Translating such a historical novel is a challenge for the translator. Arguably, the barriers to translation of the historical novel from Tamil to English are even higher since the challenges are many which include taking the readers not only to a new language situation but also to a period in the past. Before resorting to translation, the translator has to be sure that the novel to be translated meets the exacting standards of native English readers of historical fiction.

The translator Indra Neelameggham who translated the first part of Ponniyin Selvan has done her job with meticulous care. The translated version can be taken as a model to those who resort to translation of historical novels. The strategies adopted by Indra Neelameggham to make her venture palatable to English readers are highly commendable. So it is worth attempting to learn lessons from her translated work.

Keywords: standards, linguistic criteria, stylistic criteria, translational criteria, strategies, retention, compromising

\section{Introduction}

The writer Kalki is known for writing novels in Tamil based on history. A few of them are Sivakamiyin Sabadam, Partipan Kanavu, and Ponniyin Selvan. Kalki Krishnamurthy's Ponniyin Selvan excels all his other novels and attracts the readers till now. It has all the ingredients of a historical novel say historical events, love, friendship, enmity, conspiracy, vengeance and war including the style. The narration takes you to the period of the events depicted in the novel. The style is vivid and interesting. The first Part of Ponniyin Selvan is translated into English by Indra Neelameggham in 1990. Another English version of Kalki's Ponniyin Selvan has been rendered by H. Subhalakshmi Narayanan in 2016. The present study is based on Indra 
Neelameggham's English version of Ponniyin Selvan. The paper is not intended to evaluate the translation but to understand the strategies adopted by the translator for the successful translation of the historic novel Ponniyin Selvan in Tamil into English. It tries to explore the lessons or the strategies a translator can learn from such venture.

\section{A Glimpse of the First Part of Ponniyin Selvan}

First part of Ponniyin Selvan is titled as 'putuveLLam' translated as 'new floods'. It introduces one of the important characters of the novel, Vandiya Devan, who has undertaken a secret task assigned to him by the crown prince of Chola kingdom. His journey across the Chola kingdom reveals his courageous heart, cleverness and skill in using sword. The beautiful landscape of Chola kingdom of that time too gets depicted in the description of the journey. He witnesses many important events and meets important characters of the novel. First part lays foundation to the events to be followed in the next parts.

\section{Standards for Understanding Translation Strategy}

At least three criteria have to be taken into account to understand the translation strategies adopted in a translated text. They are linguistic criteria, stylistic criteria and translational criteria.

Linguistic criteria comprise of lexical, structural, and semantico-pragmatic criteria. The lexical criteria include adequate rendering of technical terms and social-cultural terms, lexical innovation of source language text (SLT) in the target language text (TLT) for maintaining a balance between them, retention of denotative meaning and preservation of connotative meaning. The structural criteria assure retention of SLT structure and modified TLT structure retaining the balance between SLT and TLT. Semantico-pragmatic criteria involve retention of social milieu of SLT into TLT, preservation of emotion/feeling of SLT in TLT, preservation of overall sense/import of SLT into TLT, accuracy/intensity/seriousness of translator in attempting the rendering of SLT into TLT, coverage of all information conveyed in SLT while creating the TLT, adequate representation of images and retention of the function of SLT into TLT.

The stylistic criteria enable the translator to choose between a number of styles depending upon the nature of the SLT and the TLT she aims at.

Translational criteria comprise of the methods of communicative translation, cognitive translation and semantic translation. Communicative translation attempts to recreate the same effect on the TL readers as received by the SL readers. Cognitive translation refers to a pre-translational procedure which may be performed on the SLT to convert it into the TL unambiguously. Semantic translation deals with the presentation of the exact contextual meaning conveyed in the SLT in TLT. In semantic translation, the translator always preserves the essence of the content in the SLT in a way the author intended, where the translator gives the prominence to the content rather than 
the lexical items. In other words, semantic translation is a semanticopragmatic oriented translation and not a structure-oriented or lexicon oriented one.

In the light of the standards of translation described above, we can discuss the strategies adopted by Indra Neelameggham in her translation.

\section{Accounting for the Period}

In a historical novel, accounting for the period of an instance is very crucial. Indra Neelameggham has taken meticulous care in transferring the concepts related to time to the target language. While doing so she even changes the period mentioned in the original text to suit the time of her translated narration. For example, in the chapter 1, we come across the following passage in which mention is made about the period of the novel in relation to the events in Ponniyin Selvan.

\begin{tabular}{|l|l|l|}
\hline $\begin{array}{l}\text { Sl. } \\
\text { No. }\end{array}$ & Original & Translation \\
\hline 1 & $\begin{array}{l}\text { vinaaTikku oru nuuRRaaNTu viitam } \\
\text { eLitil kaTantu inRaikkut } \\
\text { toLLaayirattu eNpattiraNTu (19501 } \\
\text { ezutiyatu) aaNtukaLukku muntiya } \\
\text { kaalattukkuc celvoomaaka. }\end{array}$ & $\begin{array}{l}\text { Let us travel a century for } \\
\text { every second and quickly } \\
\text { reach the times of a thousand } \\
\text { years before the present. }\end{array}$ \\
\hline 2 & aaTi aavaNi maatangkaLil & $\begin{array}{l}\text { In the windy months of } \\
\text { Aadi-Aavani (August) }\end{array}$ \\
\hline
\end{tabular}

According to the text given in the first example Ponniyin Selvan was written by Kalki in 1950 (1950l ezutiyatu). So, Kalki mentions in these lines that he takes the readers to a period before 982 (toLLaayirattu eNpattiraNTu aaNTukaLukku muntiya kaalattukku) from the time of writing Ponniyin Selvan. Since Neelameggham translated the original in 1990, she changed the original figure of 982 into thousand and translates the line as ' $a$ thousand years before the present'. In another instance where months of Tamil calendar are mentioned, Neelameggham gives the possible English equivalent of the month within parentheses: Aadi-Aavani (August).

\section{Accounting for the Location}

\begin{tabular}{|l|l|l|}
\hline $\begin{array}{l}\text { Sl. } \\
\text { No. }\end{array}$ & Original & Translation \\
\hline 1 & $\begin{array}{l}\text { tillaic ciRRamapalattukku } \\
\text { meeRkee }\end{array}$ & $\begin{array}{l}\text { West of Thillai Chittrambalam } \\
\text { (Chidambaram town) }\end{array}$ \\
\hline 2 & $\begin{array}{l}\text { caavakam, kaTaaram, } \\
\text { yavanam, miciram }\end{array}$ & $\begin{array}{l}\text { Java, Kadaram (Malaya), } \\
\text { Yavana (Greece-Rome) }\end{array}$ \\
\hline
\end{tabular}


Giving the correct location of incidents is crucial for a historical novel. Neelameggham adopts a strategy of giving the present name of the place within parentheses for the sake of the readers. She translates the phrases in the original with the added information within the brackets.

\section{Retention of Cultural Terms}

According to Edward Sapir "Each linguistic community has its own perception of the world, which differs from that of other linguistic communities, implies the existence of different worlds determined by language". Catford rationalised this theory in his book Linguistic Theory of Translation as follows: "Cultural untranslatability arises when a situational feature, functionally relevant for the source language text, is completely absent from the culture of which the TL is a part. For instance, the names of some institutions, clothes, foods and abstract concepts, amongst others." Neelameggham more or less sticks to the principle of cultural untranslatability. All the Tamil months are kept as such. The names of festivals and other culturally oriented items are retained in their original form.

\begin{tabular}{|l|l|l|}
\hline $\begin{array}{l}\text { SI. } \\
\text { No. }\end{array}$ & Original & Translation \\
\hline 1 & $\begin{array}{l}\text { aaTip patineTTaam } \\
\text { perukkanRu }\end{array}$ & $\begin{array}{l}\text { During the Adi month festival } \\
\text { of Padhinettam Perukku }\end{array}$ \\
\hline 2 & $\begin{array}{l}\text { avarkaL ooTappaaTTum, } \\
\text { veLLappaaTTum, kummiyum, } \\
\text { cintum paaTinaarkaL }\end{array}$ & $\begin{array}{l}\text { They sang traditional boat songs } \\
\text { as well as folk songs like kummi } \\
\text { and Sindhu }\end{array}$ \\
\hline 3 & $\begin{array}{l}\text { puuttuk kulungkum punnai } \\
\text { marangkaLum konnai } \\
\text { marangkaLum katampa } \\
\text { marangkaLum }\end{array}$ & $\begin{array}{l}\text { flower laden punnai, konnai and } \\
\text { kadamba }\end{array}$ \\
\hline 4 & $\begin{array}{l}\text { calli, karaTi, paRai, } \\
\text { pullaangkuzal, uTukku } \\
\text { aakiyavai ceerntu captitana }\end{array}$ & $\begin{array}{l}\text { salli, karadi, parai, udukku were } \\
\text { being tuned together. }\end{array}$ \\
\hline 5 & $\begin{array}{l}\text { kuravaik kuuttu naTakkap } \\
\text { pookiRatu }\end{array}$ & $\begin{array}{l}\text { The Kuravai Koothu (gypsy } \\
\text { dance) is about to begin }\end{array}$ \\
\hline
\end{tabular}

Adi Padhinettam Perukku, kummi and Sindhu are culturally loaded terms. Note that even names of trees are kept in the original forms as shown in the third example (punnai, konnai and kadamba). In the fourth example, the names of native instruments such as karadi, parai, udukku are kept in the native format. In the fifth example, the native diction is transferred as such to English with English equivalent in bracket 'Kuravai Koothu (gypsy dance)'.

\section{Compromising Terms for Time and Distance}

Kalki makes use of Tamil terms which are not in vogue now to denote periods and distances keeping in view of the events taking place in the historical past. 
For example, he makes use of kaata tuuram 'a sort of distance' and naazikai 'a sort of period'. Neelameggham translates them by making use of the terms league and hour respectively.

\section{Adhering to Translation Equivalents}

Neelameggham in many instances tries to make use of the translated terms instead of using the native vocabulary. The following table will illustrate this.

\begin{tabular}{|l|l|l|}
\hline $\begin{array}{l}\text { Sl. } \\
\text { No. }\end{array}$ & Original & Translation \\
\hline 1 & kuuTTaanjcooRum, cittiraannamum & Stewed rice and fancy rice \\
\hline 2 & cittiraannam mutaliyavaRRai & Picnic rice-dishes \\
\hline 3 & kuvaLaikaLum, kumutangkaLum & lily and the blue-lotus \\
\hline 4 & $\begin{array}{l}\text { iLaniir, akil, cantanam, veRRilai, } \\
\text { vellam, aval, pori }\end{array}$ & $\begin{array}{l}\text { tender coconuts, myrrh, candy, } \\
\text { jaggery, betel leaves, pressed } \\
\text { rice and puffed grain }\end{array}$ \\
\hline 5 & $\begin{array}{l}\text { joociyarkaL, reekai caastirattil } \\
\text { vallavarkaL, kuRi } \\
\text { collukiRavarkaL,viSakkaTikku } \\
\text { mantirippavarkaL }\end{array}$ & $\begin{array}{l}\text { Astrologers, expert palm } \\
\text { readers, soothsayers and } \\
\text { magicians who cured poison- } \\
\text { bites }\end{array}$ \\
\hline
\end{tabular}

The following translations are interesting to note:

\begin{tabular}{|l|l|l|}
\hline $\begin{array}{l}\text { Sl. } \\
\text { No. }\end{array}$ & Original & Translation \\
\hline 1 & $\begin{array}{l}\text { uTampellaam } \\
\text { uurtvapuNTaramaakac cantanam } \\
\text { aNintu talaiyil munkutumi } \\
\text { vaittirunta }\end{array}$ & $\begin{array}{l}\text { the sandal-paste namam } \\
\text { markings of the sect all over his } \\
\text { body; he had styled his hair into } \\
\text { a topknot on his forehead. }\end{array}$ \\
\hline 2 & $\begin{array}{l}\text { paTTai paTTaiyaat tiruniiRu } \\
\text { aNintirunta }\end{array}$ & $\begin{array}{l}\text { wearing broad ashen marks on } \\
\text { his devout body }\end{array}$ \\
\hline 3 & viirac caiva paatatuuLi paTTar & $\begin{array}{l}\text { fanatic Saiva dust-worshiping } \\
\text { priest }\end{array}$ \\
\hline 4 & $\begin{array}{l}\text { kaavi vastiram aNinta atvaita } \\
\text { canniyaaci }\end{array}$ & $\begin{array}{l}\text { the ocher-clad monk who } \\
\text { believed in the One supreme } \\
\text { Being }\end{array}$ \\
\hline 5 & veRuntaTiyanooTu & wood-brained wastrel \\
\hline 6 & pata tuuLi paTTaree & foot-dust worshipper \\
\hline 7 & kuNTaati kuNTan & well-built brute \\
\hline
\end{tabular}

The translator has taken maximum care in translating the dress, attire and appearance. Her translation of talaiyil mun kuTumi into "styled his hair into a topknot on his forehead" (as we see in sixth example) and paTTai paTTaayt thiruwiiRu into "broad ashen marks" (as we see in seventh example) stands as 
a testimony to her translation skill. In certain instances it is difficult to say whether the translation has rightly conveyed the description to the readers or not (as we see in the examples 3-5 above).

\section{Extra Information for Clarification}

Neelameggham in many instances tries to give extra information to make the native concept clear to the non-natives.

\begin{tabular}{|l|l|l|}
\hline $\begin{array}{l}\text { Sl. } \\
\text { No. }\end{array}$ & Original & Translation \\
\hline 1 & aaTi aavaNi maatangkaLil & $\begin{array}{l}\text { In the windy months of Adi- } \\
\text { Aavani (August) }\end{array}$ \\
\hline 2 & $\begin{array}{l}\text { arampaikaLaakavum } \\
\text { meenakaikaLaakavum } \\
\text { toonRinaarkaL! }\end{array}$ & $\begin{array}{l}\text { Appeared like the heavenly } \\
\text { nymphs Ramba and Menaka! }\end{array}$ \\
\hline 3 & Ponni nati & river Ponni (Cauvery) \\
\hline 4 & $\begin{array}{l}\text { teevaarap paaTalkaLaiyum } \\
\text { tiruvaaymozip } \\
\text { paacurangkaLaiyum }\end{array}$ & $\begin{array}{l}\text { captivating devotional poems - } \\
\text { Thevaram \& Thiru-vaaimozli }\end{array}$ \\
\hline 5 & manmatanaiyum & Manmatha the God of love \\
\hline 6 & $\begin{array}{l}\text { calli, karaTi, paRai, } \\
\text { pulaangkuzal, uTukku aakiyvai } \\
\text { ceerntu captittana. }\end{array}$ & $\begin{array}{l}\text { instruments like salli, karadi, } \\
\text { parai, udukku were being tuned } \\
\text { together }\end{array}$ \\
\hline
\end{tabular}

We can see from example 1, the original text does not have a word equivalent to windy 'having wind'. The translator added it as extra information as the months of Adi-Avani are windy months. Similarly in the original text (example 2) there is no equivalent for 'heavenly nymphs'. But the translator added the additional information that Ramba and Menaka are heavenly nymphs for the sake of non-natives or English readers. River Ponni is clarified as 'Cauvery' within brackets in the translated account (example 3). The poems, Thevaram and Thiru-vaaimozli have been described as 'captivating devotional poem' in the translation (example 4); unlike the original. 'Manmatha' has been specified in the translation as 'God of love' in translation (example 4). In example 5, 'salli, karadi, parai, udukku' have been explained with the additional attribute 'instruments like'.

\section{Compromising with the Administrative Terms}

The translator mostly gives the translated equivalents for the names of administrative posts which are native words. There are mismatch between the Tamil terms and the English equivalents given by the translator. The lexical gaps have been filled up by the translator by the available translation equivalents due to want of the exact translation equivalents. So the equivalents may not be exact. The following instances will exemplify this. 


\begin{tabular}{|l|l|l|}
\hline $\begin{array}{l}\text { Sl. } \\
\text { No. }\end{array}$ & Original & Translation \\
\hline 1 & taanaatikaari & head of finance \\
\hline 2 & taanyaatikaari & head of food supply \\
\hline 3 & $\begin{array}{l}\text { ciRRaracaraiyum, } \\
\text { kooTTattalaivaraiyum, } \\
\text { periyakuTittanakaararaiyum }\end{array}$ & princeling, nobleman or squire \\
\hline 4 & makaataNTa naayakarumaana & Commander-in-Chief \\
\hline
\end{tabular}

Tamil Lexicon gives the meaning 'superintendent of charities' for taanaatikaari. Similarly taanyaatikaari means 'officer for food'. atikaari in both cases is translated as 'head' which is not true; it simply means 'officer' in Tamil. taNTa naayakar means 'head of an army'; translating makaa taNTa naayakar as 'commander-in-chief' is just filling the lexical gap with the available term in the target language.

\section{Understatements}

The translation is not free from understatements or wrong statements. A few instances are found here and there. The following examples will exemplify this. Understatements are committed by the translator due to some overlooking. It is difficult to find reasons for the drawbacks.

\begin{tabular}{|l|l|l|}
\hline $\begin{array}{l}\text { Sl. } \\
\text { No. }\end{array}$ & Original & Translation \\
\hline 1 & palaac cuLai & Jack-fruit \\
\hline 2 & vaatamiTTa muuvaril oruvar & One of the debaters \\
\hline
\end{tabular}

In example 1, palaac cuLai means 'a piece of fruit inside jack fruit' and not simply 'jack-fruit'. This is a case of understatement. (Jack fruit is hyphenated unnecessarily by the translator.) In the example 2, the original means 'one among the three debaters'. This is also another instance of understatement.

\section{Over Statements}

\begin{tabular}{|l|l|l|}
\hline $\begin{array}{l}\text { Sl. } \\
\text { No. }\end{array}$ & Original & Translation \\
\hline 1 & $\begin{array}{l}\text { kurutai enRu collaateeTaa! } \\
\text { kutirai enRu col! enRaan } \\
\text { innoruvan }\end{array}$ & $\begin{array}{l}\text { "Don't say mule. Say mare," } \\
\text { corrected the other. }\end{array}$ \\
\hline 2 & ilakkooNa aaraaycci & semantic research \\
\hline
\end{tabular}

The translation is not free from over statements too. The over statements also are committed by the translator due to some overlooking.

Kurutai is the spoken (metathesized) form of kutirai 'horse'. kurutai does not mean 'mule' or 'mare'. Mule is denoted by "kooveerikkazutai" and mare 
is denoted by "peNkutirai" in Tamil. kurutai is used by Kalki as a spoken form, may be to denote the inferior quality of the horse (as visualized by the character who uttered it) and definitely not to denote mule or mare. If that is the case, Kalki would have made use of the right Tamil words mentioned above. The instances could be attributed to the translator's imagination. Similarly "ilakkooNa aaraaycci" denotes 'grammar research' and not 'semantic research' in English. The above mentioned utterances seem to be instances of overstatements and understatements respectively.

\section{Mismatches and Omissions}

There are stray instances of mismatches and omissions in the translation. The following table will exemplify this. Mismatches and omissions are committed by the translator due to some overlooking.

\begin{tabular}{|c|c|c|}
\hline $\begin{array}{l}\text { Sl. } \\
\text { No. }\end{array}$ & Original & Translation \\
\hline 1 & kamuku maTTaikaL & platters of plantain-flower petals \\
\hline 2 & $\begin{array}{l}\text { viruntukkup piRaku } \\
\text { kaLiyaaTTam, caamiyaaTTam, } \\
\text { kuravaik kuuttu ellaam } \\
\text { naTaipeRum. Kuravaik kuuttup } \\
\text { paarkka veeNTum enRu enakku } \\
\text { aacai! }\end{array}$ & $\begin{array}{l}\text { After the feasting there would be } \\
\text { several entertainments: music, } \\
\text { pantomimes, miracle plays, gypsy } \\
\text { dancers and mystic oracles. I wish } \\
\text { to see the gypsy dance and hear } \\
\text { the oracle. }\end{array}$ \\
\hline 3 & $\begin{array}{l}\text { calli, karaTi, paRai, } \\
\text { pullaangkuzal, uTukku } \\
\text { aakiyavai ceerntu captittana }\end{array}$ & $\begin{array}{l}\text { Several kinds of drums, flutes, } \\
\text { pipes and instruments like salli, } \\
\text { karadi, parai, udukku } \\
\text { were being tuned together. }\end{array}$ \\
\hline
\end{tabular}

In example 1, kamuku maTTai means 'platters of areca nut' not 'platters of plantain-flower petals' as given in the translation. In example 2, there is no mention of 'miracle plays' and 'mystic oracles' in the original. There are many mismatches in the $3^{\text {rd }}$ example. The original has only the following statement: calli, karaTi, paRai, pullaangkuzal, uTukku aakiyavai ceerntu captittaana which can be translated as 'salli, karadi, parai, flute, udukku were being tuned together'. This series is distorted in the translation with the addition of 'Several kinds of drums, flutes, pipes'; of course flute which comes after parai in the original.

\section{Retention of Metaphors and Similes}

The metaphors and similes used by Kalki are retained in the translation with the original connotation. The following instances will justify this observation.

Translation of metaphor and simile is always a challenge to a translator. The selection of parallel metaphor or simile may sometimes cause confusion and misunderstanding. The translator of Ponnin Selvan has to be appreciated for carrying out the meaning conveyed by these two types of expression to the 
TL successfully almost in all her renderings. For example the simile "veNciRakukaLai virittuk koNTu niiril mitantuvarum annap paTcikaLaip pool" is translated as "swiftly like white swans floating with wide-spread wings'. The selection of translational equivalents carries the original meaning as such in this expression.

\begin{tabular}{|l|l|l|}
\hline $\begin{array}{l}\text { Sl. } \\
\text { No. }\end{array}$ & Original & Translation \\
\hline 1 & $\begin{array}{l}\text { veLLaip paaykaL virikkappaTTa } \\
\text { eezeTTup periya ooTangkaL, } \\
\text { veNciRakukaLai virittuk koNTu } \\
\text { niiril mitantuvarum annap } \\
\text { paTcikaLaip pool, meelak } \\
\text { kaaRRinaal untappaTTu viraintu } \\
\text { vantu koNTiruntana. }\end{array}$ & $\begin{array}{l}\text { About seven or eight large boats } \\
\text { with white, spreading sails filled } \\
\text { with the breeze were coming } \\
\text { swiftly like white swans } \\
\text { floating with wide-spread } \\
\text { wings. }\end{array}$ \\
\hline 2 & $\begin{array}{l}\text { oru maamalaic cikarattin miitu } \\
\text { kariyakoNTal onRu tangkiyatu } \\
\text { pool }\end{array}$ & $\begin{array}{l}\text { looked like a dark cloud resting } \\
\text { atop a mountain peak. }\end{array}$ \\
\hline 3 & $\begin{array}{l}\text { ungkaL aRivu ulakkai } \\
\text { kozuntutaan! }\end{array}$ & $\begin{array}{l}\text { Your brains are like budding } \\
\text { shoots on a pounding block. }\end{array}$ \\
\hline 4 & $\begin{array}{l}\text { kaTampuur maaLikaiyin kariya } \\
\text { periya mattakajattin miitu } \\
\text { pazuveeTTaraiyar, erumaikkaTaa } \\
\text { miitu ematarman varuvatu pool } \\
\text { vantu koNTiruntaar. }\end{array}$ & $\begin{array}{l}\text { Lord Pazluvoor was coming } \\
\text { seated on the dark, huge } \\
\text { elephant from Kadamboor Fort: } \\
\text { like Yama, the God of } \\
\text { Justice seated upon a huge } \\
\text { water-buffalo! }\end{array}$ \\
\hline
\end{tabular}

The same thing can be said for the simile in the second example too. But metaphors are not easily amenable to translation. The metaphor used in TL in the example 3 is a difficult one as it is very much a socio-cultural term which is unknown to the TL readers. "ulakkai kozuntu" which literally means 'rounded end of a pestle' (as given by Tamil Lexicon) which metaphorically means 'stupid person'. The literally translation of metaphor into TL does not carry the metaphorical sense of SL to TL properly. In the $4^{\text {th }}$ example the simile "erumaikkaTaa miitu ematarman varuvatu pool" is translated as "like Yama, the God of Justice seated upon a huge water-buffalo'. Kriyavin taRkaalat tamiz akaraati (KTTA) gives the meaning of eman as 'god of death (who rides he-buffalo)' and erumai as 'buffalo'. But the translator translates ematarman as 'God of Justice' which may be due to the attributive head tarman 'god of justice' and erumai as 'water-buffalo'. Tamil Lexicon gives the meaning of eman as 'god of death' and erumai as 'buffalo'. The translator might have preferred 'water-buffalo' with the attributive noun 'water' to distinguish it from other species of oxen. 


\section{Vivid Style of Translation}

The translator adopts a style of translation which definitely makes the reader to feel that they are reading the original. The translation at the word, phrasal level and sentential level is worth commendable. The whole of the translated book is full of such instances.

\begin{tabular}{|l|l|l|}
\hline $\begin{array}{l}\text { Sl. } \\
\text { No. }\end{array}$ & \multicolumn{1}{|c|}{ Original } & \multicolumn{1}{c|}{ Translation } \\
\hline 1 & $\begin{array}{l}\text { tanta niRat tennangkurttukaLal } \\
\text { capparangkaTTi izuttukkoNTu }\end{array}$ & $\begin{array}{l}\text { dragging their carts covered with } \\
\text { canopies of sandal-colored, } \\
\text { supple coconut-leaves, }\end{array}$ \\
\hline 2 & $\begin{array}{l}\text { kariya tirumeeniyar oruvar } \\
\text { viiRRiruntaar. mattakajattin meel } \\
\text { anta viirar }\end{array}$ & $\begin{array}{l}\text { A dark, well-built man seated on } \\
\text { a finely decorated elephant }\end{array}$ \\
\hline 3 & $\begin{array}{l}\text { min oLiyuTan kaNNap paRitta } \\
\text { anta vaaL cuzanRa veekattinaal } \\
\text { avanuTaiya kaiyil tirumaalin } \\
\text { cakkaraayutattai vaittuk koNTu } \\
\text { cuzaRRuvatu pool toonRiyatu }\end{array}$ & $\begin{array}{l}\text { The swirling sword flashing like } \\
\text { swift lightning in his hand } \\
\text { appeared like God } \\
\text { Vishnu's spinning Chakra } \\
\text { (discus) }\end{array}$ \\
\hline
\end{tabular}

The above mentioned examples stand to exemplify the vivid style of translation used by the translator.

\section{Adherence to Discourse and Tempo}

Coherence in the discourse is the salient feature of novels. The tempo has to be kept to induce the reader to continue reading. The translator successfully maintains the coherence in the discourse in her rendering as well as she keeps the tempo of the original intact. The following instances will justify this observation.

\begin{tabular}{|c|c|c|}
\hline $\begin{array}{l}\text { Sl. } \\
\text { No. }\end{array}$ & Original & Translation \\
\hline 1 & $\begin{array}{l}\text { aakaa! Itu evvaLavu } \\
\text { piramaaNTamaana eeri? ettnai } \\
\text { niiLam? ettnaai akalam? toNTai } \\
\text { naaTTil pallavap peeraracarkaLin } \\
\text { kaalattil amaitta eerikaLellaam } \\
\text { inta eerikku munnaal ciRu } \\
\text { kuLangkuTTaikaL enRee } \\
\text { collattoonRum allavaa? vaTa } \\
\text { kaaveeriyil viiNaakac cenRu } \\
\text { kaTalil vizum taNNiiraip } \\
\text { payanpaTuutuvataRkaak } \\
\text { maturaikoNTa paraantkarin }\end{array}$ & $\begin{array}{l}\text { Aha! How huge is this lake? } \\
\text { How wide and how long? Can } \\
\text { we not say that the tanks built } \\
\text { by the great Pallava monarchs } \\
\text { in the Thondai Kingdom are } \\
\text { mere ponds and pools } \\
\text { compared with this immense } \\
\text { reservoir? Did not Prince } \\
\text { Raja-aditya son of King } \\
\text { Paranthaka who conquered } \\
\text { Madurai, think of building } \\
\text { this great tank to conserve the }\end{array}$ \\
\hline
\end{tabular}




\begin{tabular}{|l|l|l|}
\hline & $\begin{array}{l}\text { putalvar iLavaracar iraajaatittar } \\
\text { ita kaTal poonRa eeriyai amaikka } \\
\text { veeNTumenRu eNNinaaree? }\end{array}$ & $\begin{array}{l}\text { waters of the North Cauvery } \\
\text { which were going wastefully } \\
\text { into the sea? }\end{array}$ \\
\hline $\begin{array}{l}\text { "aTaTee! itu enna vintai! unakku } \\
\text { eppaTi avaLuTaiya niRattaip } \\
\text { paRRit teriyum? nii avaLaip } \\
\text { paarttirukkiRaayaa, enna? engkee, } \\
\text { eppaTi paarttaay? } \\
\text { pazuveeTTaraiyarukku maTTum } \\
\text { itu terintaal, un uyir } \\
\text { unnuTaiyatala..." }\end{array}$ & $\begin{array}{l}\text { "Hoy! What is this wonder? } \\
\text { complexion? Why, have you } \\
\text { seen her? Where? How did } \\
\text { you see her? If Lord } \\
\text { Pazluvoor knows of this, your } \\
\text { life is not yours!" }\end{array}$ \\
\hline
\end{tabular}

The translator has defiantly translated these emotion laden passages using relevant translational equivalents keeping in mind the discourse structure and the tempo of the discourse. At the same time the translator resorts to translation with the native language style. Sometimes this type distortion gives the translation the source language flavour which most of the Indian translators invariably do. One can see such nativization or Indianization in novels written in English by the Indian authors.

\section{Persistent Style}

The translator retains the narrative style of the Kalki while resorting to translation. The flow of the original book is retained in the translation too. The whole translation stands to testify this statement. There are many joyous occasions in this volume with joyous poems. The translator keeps the style of the original by translating these poems without sacrificing the tempo of the original.

\begin{tabular}{|l|l|l|}
\hline $\begin{array}{l}\text { Sl. } \\
\text { No. }\end{array}$ & Original & Translation \\
\hline 1. & $\begin{array}{l}\text { "vaTavaaRu pongki varutu } \\
\text { vantu paarungkaL, paLLiyaree! } \\
\text { veLLaaRu viraintu varutu } \\
\text { veeTikkaip paarungkaL, } \\
\text { tooziyaree } \\
\text { kaaveeri puraNTu varutu } \\
\text { kaaN vaarungkaL, paangkiyaree!" }\end{array}$ & $\begin{array}{l}\text { Come, oh ye young maidens, } \\
\text { Look at the North river } \\
\text { bubbling by! } \\
\text { Come watch, oh ye friends, } \\
\text { Look at the White river } \\
\text { rushing by! } \\
\text { Come, oh come all ye girls, } \\
\text { To look at the Cauvery } \\
\text { tumbling by! }\end{array}$ \\
\hline 2 & $\begin{array}{l}\text { "paciyum piNiyum pakaiyum azika! } \\
\text { pazaiyum vaLamum tanamum }\end{array}$ & $\begin{array}{l}\text { Let hunger and disease be } \\
\text { destroyed; } \\
\text { Let enmity be routed; } \\
\text { Let rain and fertility increase; } \\
\text { Let bounty grow boundless. }\end{array}$ \\
\hline
\end{tabular}


Throughout the translated text, the translator maintains her style keeping in mind the historically oriented source language style.

\section{Successful Transferring of the Scenery Descriptions in the Original}

The translator is very successful in transferring the description of scenery beauties in the original as such in translation. There are many such instances of such vivid descriptions transferred to the translation. The following is one among many.

\begin{tabular}{|l|l|l|}
\hline $\begin{array}{l}\text { Sl. } \\
\text { No. }\end{array}$ & Original & Translation \\
\hline 1 & $\begin{array}{l}\text { aaTip patineTTaam perukkanRu } \\
\text { coozanaaTTu natikaLilellaam } \\
\text { veLLam irukaraiyum toTTuk } \\
\text { koNTu ooTuvatu vazakkam. anta } \\
\text { natikaLiliruntu taNNiir peRum } \\
\text { eerikaLum puuraNamaaka } \\
\text { nirampik karaiyin ucciyait toTTuk } \\
\text { koNTu alaimootik koNTiruppatu } \\
\text { vazakkam. vaTa kaaveeri enRu } \\
\text { paktarkaLaalum koLLiTam enRu } \\
\text { pootu makkaLaalum } \\
\text { vazangkappaTTa natiyiliruntu } \\
\text { vaTavaaRRin vaziyaakat taNNiir } \\
\text { vantu viira naaraayaNa eeriyil } \\
\text { flood waters touching both } \\
\text { festival of Padhinettam } \\
\text { Perukku. The lakes fed by these } \\
\text { rivers would also be filled to } \\
\text { capacity, with waves jostling } \\
\text { katala colliding upon their } \\
\text { embankments. Waters from the } \\
\text { river called North Cauvery by } \\
\text { the devout, but commonly } \\
\text { known as Kollidam, rushed into } \\
\text { the Veera Narayana Lake, } \\
\text { through the Vadavaru stream } \\
\text { and made it a turbulent sea. }\end{array}$ \\
\hline
\end{tabular}

The text is full of such instances. The translator adherently follows the source text in the description of sceneries which is very much essential for carrying the readers to the historical past.

\section{Missing of Information by the Illustrative Pictures}

In spite of the inspiring translation, the translated version misses the illustrative pictures by Maniyan who captured the events and characters in his pictures which appeared along with the weekly narration of the novel in the Kalki magazine. The pictures captivated the imagination of millions of readers, taking them back in time and space. Rajaji who was a great statesman of that time and a well wisher of Kalki made the following comment in his preface to Ponniyin Selvan: "Manian's illustrations will tempt even good people to steal." There is no doubt that the translation misses the information conveyed by the illustrative pictures appeared in the magazine.

\section{Conclusion}

From the point of view of standards of translation explained in the beginning an attempt has been made here to understand the strategies adopted by the 
translator to render the original in Tamil into English. We can guess that the translation is meant for non-native speakers, especially for those who know English and not Tamil. The translator has to assume that the readers of the translation are not acquainted to the socio-cultural environment of the novel under consideration. The translator's dictions should be understandable to the readers and at the same time should not mislead them. In spite of the stray instances of lacunae, we must say that the translator has successfully translated Ponniyin Selvan in Tamil into English. The strategies adopted by the translator are highly commendable. A translator can learn many things from the translation strategies adopted by Neelameggham.

\section{References}

CATFORD, J. C. 1965. A Linguistic Theory of Translation. London: Oxford University Press.

BassnetT, S. 1980. Translation Studies. London: Methuen \& Co. Ltd.

BAssnett, S., and LefEVERE, A. 1998. Constructing Cultures: Essays on Literary Translation. Clevedon: Multilingual Matters.

Kriyaavin taRkaalat tamiz akaraati. Chennai: Cre-A

Krishnamurthy, KalKI. 1950. Ponniyin Selvan Part A: Putuvellam. Electronic form, Project Madurai.

NeElameggham, IndRA. 1993. English Translation of Ponniyin Selvan Part A: New Floods by Kalki Krishnamurthy. Project Madurai.

NEWMARK, P. 1988. A Textbook of Translation. New York \& London: Prentice Hall.

NIDA, E. A. 1964. Towards a Science of Translating: With Special Reference to Principles and Procedures Involved in Bible Translating. Leiden: E. J. Brill.

NIDA, E. A., and TABER, C. R. 1982. The Theory and Practice of Translation. Leiden: E.J. Brill.

SAPIR, E. 1956. Culture, Language and Personality. Berkeley, Los Angeles: University of California Press.

Tamil Lexicon (six volumes). 1982. Madras: Madras University. 